\title{
Pemberdayaan Masyarakat tentang Pemanfaatan Tanaman Saga (Abrus Precatorius L) di Desa Tanahbaru Pakisjaya Karawang
}

\author{
Eri Widianto1, Dian Budhi Santoso², Kardiman ${ }^{3}$, Asep Erik Nugraha ${ }^{4}$ \\ ${ }^{1,3}$ Program Studi Teknik Mesin, Fakultas Teknik, Universitas Singaperbangsa Karawang \\ ${ }^{2}$ Program Studi Teknik Elektro, Fakultas Teknik, Universitas Singaperbangsa Karawang \\ ${ }^{4}$ Program Studi Teknik Industri, Fakultas Teknik, Universitas Singaperbangsa Karawang \\ Email: eri.widianto@ft.unsika.ac.id ${ }^{1}$,dian.budhi@ft.unsika.ac.id ${ }^{2}$, \\ kardiman@ft.unsika.ac.id ${ }^{3}$, nugraha_ae@yahoo.co.id ${ }^{4}$
}

\begin{abstract}
ABSTRAK
Tanaman obat saat ini banyak digunakan baik sebagai obat dan perawatan kesehatan. Tanaman obat menjadi sumber bahan baku penting yang sebelumnya belum diketahui kandungan kimianya. Tanaman Saga (Abrus Precatorius L) banyak ditemukan di Indonesia seperti di Desa Tanahbaru, Pakisjaya, Karawang. Tanaman Saga banyak mengandung flavonoid, terpenoid, tanin, alkaloid dan saponin. Tanamn Saga dapat digunakan sebagai antiseptik, anti virus, anti malaria dan anti fertilitas. Pada kegiatan ini bertujuan untuk pemberdayaan masyarakat Desa Tanahbaru tentang pemanfaatan tanaman Saga. Kegiatan ini dilakukan dengan evaluasi kegiatan awal, sosialisasi, pendampingan dan evaluasi akhir kegiatan.
\end{abstract}

Kata Kunci: pemberdayaan; tanaman Saga; tanaman obat.

\section{ABSTRACT}

Medicinal plants are being used as a drug and health care delivery system. Medicinal plants can be important source of previously unknown chemical substances. Saga (Abrus Precatorius L) abundantly found in Indonesia such as in Tanahbaru village, Pakisjaya, Karawang. Saga principally contains falvonoids, terpenoid, tanin, alkaloids dan saponin. It have been for antiseptic, anti-viral, anti-malarial, and antifertility. This activity aims to community empowerment in Tanahbaru village about Saga plants. Activities are conducted by initial evaluation of activities, socialization, assistance and final evaluation activities.

Keywords: empowerment; medicinal plants; Saga plants.

\section{PENDAHULUAN}

Kabupaten Karawang berada di bagian utara Propinsi Jawa Barat dengan luas wilayah $1.753,27 \mathrm{~km}^{2}$ atau 3,73 persen dari luas Propinsi Jawa Barat. Luas seluruh lahan di Kabupaten Karawang adalah 175.327 Ha dengan perincian lahan sawah seluas $97.529 \mathrm{Ha}$ dan lahan kering seluas 77.798 Ha. Kabupaten
Karawang merupakan salah satu daerah yang memiliki lahan yang subur di Jawa Barat, sehingga sebagian besar lahannya digunakan untuk pertanian. Secara geografis Kabupaten Karawang terletak antara $107^{\circ} 02^{\prime}-107^{\circ} 40^{\prime}$ Bujur Timur 5 56'$6^{\circ} 34^{\prime}$ Lintang Selatan, termasuk daerah yang relatif rendah, mempunyai variasi kemiringan 
wilayah antara $0-1.279$ meter di atas permukaan laut dengan kemiringan wilayah $\quad 0-2 \% \quad$ (datar), $\quad 2-15 \%$ (bergelombang), 15-40\% (curam) dan di atas $40 \%$ (sangat curam), dengan suhu rata-rata $27{ }^{\circ} \mathrm{C}$. Kabupaten Karawang memiliki wilayah yang cukup luas, dengan topografi yang beraneka ragam.

Sediaan obat bahan alam sebagai warisan budaya nasional bangsa Indonesia dirasa semakin berperan dalam pola kehidupan masyarakat dari sisi kehidupan maupun perekonomian. Masyarakat semakin terbiasa menggunakan obat sediaan alam dan semakin percaya akan kemanfaatannya bagi kesehatan. Salah satu contoh tumbuhan yang digunakan sebagai obat tradisional adalah Abrus precatorius $L$ atau di Indonesia dikenal dengan tanaman Saga. Saga berkhasiat sebagai pengencer dahak (mukolitik) (Novianan, 2013). Daun saga mempunyai efektivitas sebagai obat batuk yang bekerja memacu sekresi mukosa dan trakea. Selain itu, saga mempunyai indikasi untuk pencegahan dan penyembuhan sariawan, sakit tenggorkan dan radang amandel (Indah dan Darwati, 2013:86). Saga merupakan salah satu tumbuhan yang dapat digunakan sebagai antibakteri (Chaudhari, dkk, 2012; Garaniya dan Bapodra, 2014) dan daunnya digunakan unutk mengobati radang tenggorokan (DepKes RI, 2000). Ekstrak daun saga memiliki aktivitas antibakteri terhadap Streptococcus pyogenes yang merupakan bakteri penyebab radang tenggorokan (Prajogo dkk., 1993; Verma, 2016). Berdasarkan penelitian Gnanavel dan Saral (2013) ekstrak etanol daun saga mengandung beberapa senyawa kimia aktif yaitu flavonoid, terpenoid, tanin, alkaloid dan saponin yang berpotensi sebagai antibakteri alami untuk pengobatan radang tenggorokan.

Desa Tanahbaru Kecamatan Pakisjaya Karawang memiliki lahan tanah yang subur dan memiliki potensi tanaman saga yang melimpah. Namun masyarakat belum menyadari manfaat dari tanaman saga dan dianggap sebagai tanaman liar. Tanaman saga merupakan tanaman merambat yang biasa tumbuh liar di hutan, ladang, halaman dan tempat lain pada ketinggian 300 sampai 1000 m dari permukaan laut (DepKes RI, 2000). Tanaman saga memiliki manfaat multiguna yang tidak hanya secara ekologis, skala rumah tangga sampai kebutuhan industri. Salah satu upaya untuk mempertahankan kelestariannya yaitu melakukan pengelolaan dan pembudidayaan yang tepat.

Berdasarkan uraian di atas, maka dalam kegiatan pengabdian pada masyarakat ini akan dilakukan kerja sama antara pihak pengabdi dengan masyrakat Desa Tanahbaru Pakisjaya Karawang. Dimana masyarakat Desa Tanahbaru dikordinasi oleh Kelompok Tani dan Kelompok Karang Taruna. Beberapa kegiatan yang akan dilakukan yaitu: a) sosialisasi dan pemaparan program rencana kegiatan abdimas; b) sosialisasi kegunaan, manfaat dan 
budidaya tanaman Saga; c) pembuatan teh daun Saga. Kegiatan abdimas ini diharapkan mampu meningkatkan pemahaman akan tanaman obat alami sehingga tidak bergantung pada obat-obatan kimia yang ada di pasaran. Selain itu, budidaya tanaman Saga diharapkan meningkatkan perekonomian masyarakat, dengan memasarkan bibit tanaman saga ke pasar yang lebih luas.

\section{METODE PENELITIAN}

Program pengabdian kepada Masyarakat dilakukan menggunakan prinsip bahwa setiap inovasi yang diterima oleh Mitra melalui proses, mendengar, mengetahui, mencoba, mengevaluasi, menerima, meyakini dan melaksanakan. Melalui prosesproses tersebut diharapkan inovasi dan teknologi dapat diterima secara berkesinambungan, serta target sasaran mempunyai kemampuan untuk melakukan analisis terhadap perkembangan usahanya, serta mampu mengembangkan inovasi yang telah dikuasainya. Penyampaian inovasi kepada masyarakat dilakukan melalui tahapan penjelasan, diskusi, praktek serta dilakukan tahapan pendampingan.

Kegiatan pengabdian kepada masyarakat di Desa Tanahbaru Pakisjaya Karawang diantaranya:

1. Sosialisasi Program: Karena kegiatan melibatkan berbagai pihak, maka sosialisasi perlu dilakukan karena akan turut terlibat dalam aktivitas pendampingan, serta secara langsung turut berperan dalam mencapai keberhasilan kegiatan.

Selain itu, dilakukan juga sosialisasi mengenai manfaat dan kegunaan, budidaya dan pengolahan tanaman saga. Metode yang digunakan berupa ceramah, diskusi dan bimbingan

2. Perancangan dan Pembuatan Green House: Pembuatan greenhouse dimulai dari persiapan bahan dan peralatan yang dibutuhkan seperti pipa PVC, plastik UV, screen net, kayu, baut, knock tee, paku ulir, paku biasa, palu, dll. Selanjutnya pemilihan lahan serta persiapan tanaman saga.

3. Pembuatan obat alami teh daun Saga: Pembuatan obat alami dari tanaman saga untuk tahap awal yaitu untuk obat sariawan berupa teh daun saga. Dan untuk tahap selanjutnya dapat digunakan untuk obat batuk dan tenggorokan dalam bentuk tablet atau kapsul.

Mitra yang terlibat dalam program pengabdian kepada masyarakat ini adalah kelompok Tani dan Karang Taruna Desa Tanahbaru Kecamatan Pakisjaya Karawang. Sasaran kegiatan adalah seluruh lingkungan dan masyarakat desa Tanahbaru Kecamatan Kotabaru. Partisipasi mitra program ini diperlukan dalam mensukseskan terlaksananya program kegiatan ini, antara lain:

1. Memberikan informasi data-data kondisi lingkungan, lahan, dan usaha mikro serta operasionalnya, serta persiapan tanaman saga. 
2. Memberikan masukan tentang posisi lahan yang cocok dan desain green house yang diharapkan.Mendukung pelaksanaan

3. pelatihan, sosialisasi dan perancangan green house.

4. Mempelajari manfaat dan kegunaan tanaman saga serta mempelajari potensi sesuai dengan kebutuhan proses lanjutan dan produk yang akan dibuat.

5. Berkordinasi secara aktif dengan pelaksanaan program kegiatan pengabdian kepada masyarakat.

\section{HASIL DAN PEMBAHASAN}

\section{Survei Lokasi dan Potensi}

Lokasi kegiatan pengabdian kepada masyarakat di Desa Tanahbaru Kecamatan Pakisjaya Karawang. Kegiatan diawali dengan survei lokasi dan potensi Tanaman Saga. Pada saat survei juga dilakukan tanya jawab dan diskusi dengan warga setempat guna persiapan sosialisasi dan pelaksanaan kegiatan pengabdian. Bibit Tanaman Saga yang sudah tumbuh ditanam pada polybag. Bibit juga dapat diperoleh dengan cara menanam biji Saga.

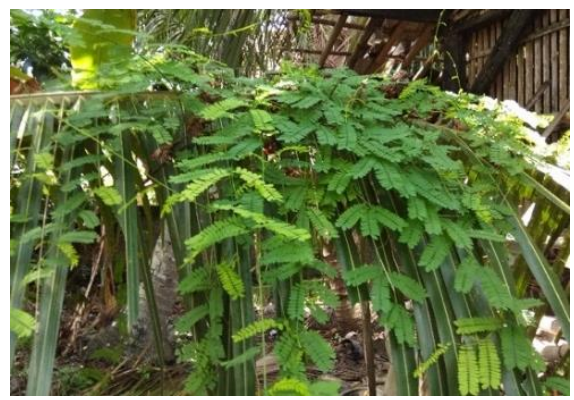

Gambar 1: Potensi Tanaman Saga di Desa Tanahbaru

\section{Sosialisasi Kegiatan}

Sosialisasi program pengabdian kepada masyarakat mengenai pemanfaatan Tanaman Saga dilakukan melalui ceramah dari tim pelaksana, diskusi, tanya jawab serta pemaparan materi dan penjelasan mengenai pengertian, manfaat dan cara pengolahan Tanaman Saga kepada warga masyarakat Desa Tanahbaru, Pakisjaya-Karawang. Kegiatan berlangsung dengan baik dengan antusias yang tinggi dari masyarakat. Tanya jawab dan diskusi menjadikan kegiatan sosialisasi berjalan sangat interaktif.

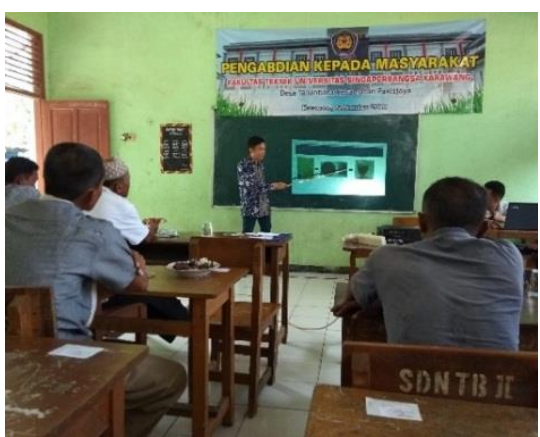

Gambar 2: Pemaparan Materi tentang pemanfaatan Tanaman Saga

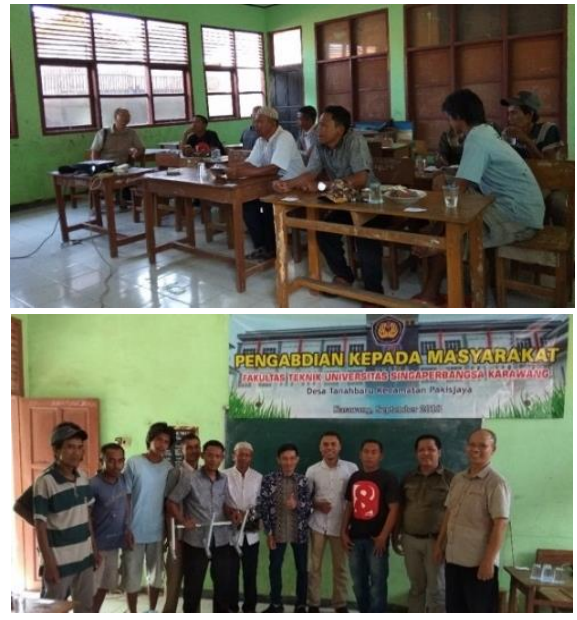

Gambar 3: Sosialisasi pemanfaatan Tanaman Saga 


\section{Pelaksanaan Kegiatan}

Setelah kegiatan sosialisasi dilaksanakan, dilanjutkan dengan praktek dilapangan. Beberapa kegiatan yang dilakukan yang pertama yaitu pembibitan Tanaman Saga. Pembibitan Tanaman Saga dapat dilakukan dengan pemindahan bibit yang baru tumbuh, dapat juga dilakukan dengan biji Tanaman Saga. Bibit Saga dapat langsung dipindahkan ke dalam polybag.

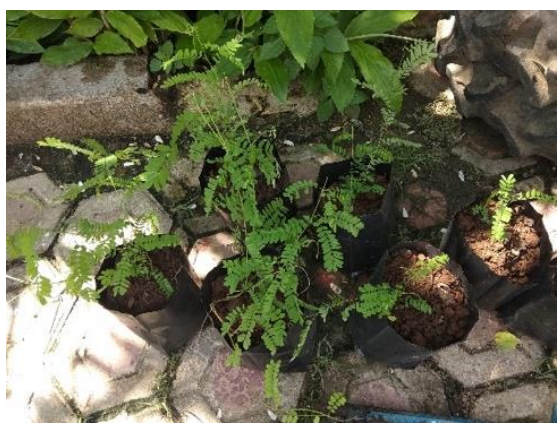

Gambar 4: Pembibitan Tanaman

$$
\text { Saga }
$$

Dalam meningkatkan bidang
pertanian terutama di bidang
pembudidayaan tanaman, ada
beberapa cara yang biasa dilakukan
oleh para petani atau para
oleh para petani atau para pembudidaya tanaman. Sebagai salah satu contohnya yaitu dengan membudidayakan tanaman dengan menggunakan cara yaitu green house. Selanjutnya dilakukan praktek pembuatan greenhouse di Desa Tanahbaru. Dengan greenhouse beberapa kondisi lingkungan berikut dapat dihindari, antara lain:

1) Perubahan suhu dan kelembaban yang fluktuatif

2) Akibat buruk yang di timbulkkan dari radiasi sinar matahari jenis sinar ultra violet dan sinar infrared

3) Kekurangan air pada musim kemarau dan kelebihan air pada musim penghujan.

4) Hama dan binatang pengganggu serta penyakit tanaman seperti jamur dan bakteri.

5) Tiupan angin kencang yang dapat merobohkan tanaman dan merusak daun

6) Tiupan angin dan serangga yang dapat menggagalkan proses penyerbukan bunga

7) Akibat buruk dari polusi udara

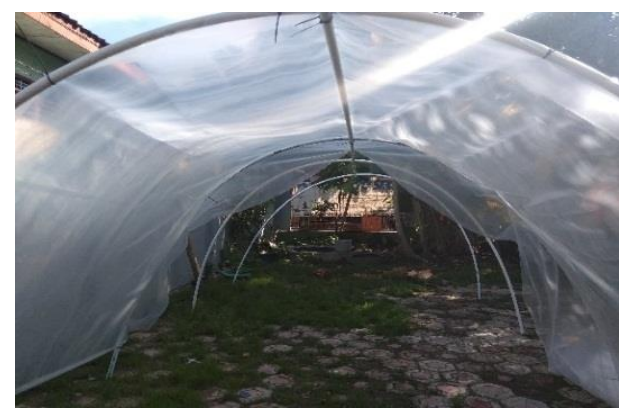

Gambar 5: Praktek pembuatan grennhouse dari pipa PVC

Selanjutnya dilakukan sosialisasi pembuatan teh daun Saga. Teh daun Saga dibuat secara manual dengan cara memotong-motong daun Saga, kemudian dipanaskan sampai kering. Selanjutnya daun Saga yang sudah kering dimasukkan ke dalam kantong teh, seperti pada Gambar 6. Saga berkhasiat sebagai pengencer dahak (mukolitik) (Novianan, 2013). Daun saga mempunyai efektivitas sebagai obat batuk yang bekerja memacu sekresi mukosa dan trakea. Selain itu, saga mempunyai indikasi untuk pencegahan dan penyembuhan 
sariawan, sakit tenggorkan dan radang amandel (Indah dan Darwati, 2013:86). Saga merupakan salah satu tumbuhan yang dapat digunakan sebagai antibakteri (Chaudhari, dkk, 2012; Garaniya dan Bapodra, 2014) dan daunnya digunakan unutk mengobati radang tenggorokan (DepKes RI， 2000). Ekstrak daun saga memiliki aktivitas antibakteri terhadap Streptococcus pyogenes yang merupakan bakteri penyebab radang tenggorokan (Prajogo dkk., 1993; Verma, 2016). Berdasarkan penelitian Gnanavel dan Saral (2013) ekstrak etanol daun saga mengandung beberapa senyawa kimia aktif yaitu flavonoid, terpenoid, tanin, alkaloid dan saponin yang berpotensi sebagai antibakteri alami untuk pengobatan radang tenggorokan.

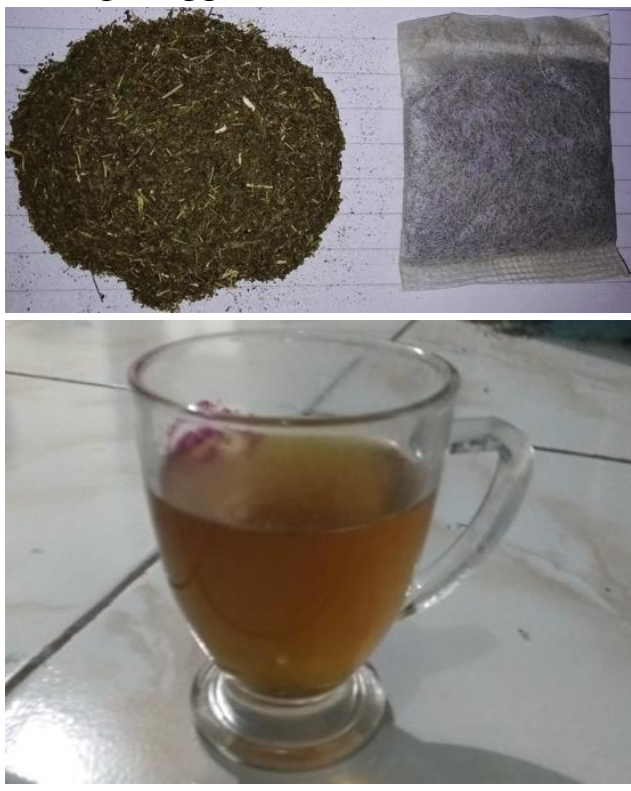

Gambar 6: Teh daun Saga

\section{SIMPULAN}

Kegiatan pengabdian kepada masyarakat yang telah dilakukan dapat diambil kesimpulan bahwa:
1. Pelaksanaan kegiatan pengabdian kepada masyarakat di Desa Tanahbaru, Kecamatan Pakisjaya Karawang berupa sosialisasi dan pelaksanaan kegiatan berupa pembibitan tanaman, praktek pembuatan greenhouse, serta pembuatan teh daun Saga.

2. Pelaksanaan kegiatan pengabdian masyarakat ini sangat membantu masyarakat terutama memberikan informasi dan metode sederhana pembuatan greenhouse PVC, serta membuat obat alami berupa teh daun Saga yang diharapkan menjadi produk unggulan Desa Tanahbaru.

\section{UCAPAN TERIMA KASIH}

Karya tulis ini adalah hasil dari pengabdian kepada masyarakat yang dilakukan oleh Tim Pengabdian Unsika. Ucapan terimakasih diucapkan kepada LPPM Unsika yang telah memfasilitasi kegiatan pengabdian ini melalui Hibah Internal Tahun Anggaran 2018.

\section{DAFTAR PUSTAKA}

Buku Data Status Lingkungan Hidup (SLH) Kabupaten Karawang. 2013

Chaudhari, K.S., Sharma, R., Pawar, P.S., and Kashikar., V.A, 2012, Pharmacological activities of Abrus precatorius Linn. - A Review, International Journal of Ayurvedic and Herbal Medicine, 2:2, 336-348 
DepKes RI, 2000, Inventaris Tumbuhan Obat Indonesia, Jilid I, Departemen Kesehatan Republik Indonesia, Jakarta, 34.

Garaniya, N. and Bapodra, A., 2014, Ethno Botanical and Phytophrmacological Potential of Abrus Precatorius L.: A review, Asian Pacific Journal of Tropical Biomedicine, 4, 27-34.

Gnanavel, V. and Saral, A.M., 2013, GC-MS Analysis of Petroleum Ether and Ethanol Leaf Extracts from Abrus Precatorius Linn, International Journal of Pharma and Bio Sciences; 3, 37-44.

Indah SY \& Darwati, (2013). Keajaiban Daun, Tibun Media, Surabaya
Laporan Status Lingkungan Hidup (SLH) Kabupaten Karawang. 2013

Noviana, Andita. (2013). Uji Aktivitas Mukolitik Infusa Daun Saga (Abrus precatorius L.) Secara In Vitro [Skripsi], Fakultas MIPA Universitas Islam Bandung, Bandung.

Prajogo, B., Dyatmiko, W., Santa, IGP., dan Sutarjadi., 1993, Aktivitas Antimikroba Daun Arus precatorius, Warta Tumbuhan Obat Indonesia, 2,2, 49.

Verma,S., 2016, Phytochemical and Pharmacological Study on Abrus precatorius, Asian Journal of Plant Science and Research, vol 6, 24-26. 